\title{
DESAIN MODEL PENANGANAN KELUHAN KONSUMEN PRODUK INDIHOME DI KOTA AMBON (STUDI KASUS: PT. TELKOM TBK. WILAYAH MALUKU)
}

\author{
Johan Marcus Tupan ${ }^{1}$, Victor Oryon Lawalata ${ }^{2}$ \\ ${ }^{1}$ johan.tupan@fatek.unpatti.ac.id, ${ }^{2}$ victor.lawalata@,fatek.unpatti.ac.id \\ Program Studi Teknik Industri, Fakultas Teknik, Universitas Pattimura
}

\begin{abstract}
ABSTRAK
IndiHome merupakan layanan triple-play dari PT. Telkom Tbk yang terdiri dari Internet, Telepon Rumah dan IPTV. Kualitas layanan menjadi isu penting ketika banyak keluhan dari pelanggan IndiHome dan cenderung berpengaruh pada tingkat kepuasan terhadap layanan perusahaan ini. Penelitian ini bertujuan menganalisis tingkat kepentingan/harapan konsumen produk IndiHome terhadap penanganan keluhan yang diberikan PT. Telkom Tbk; menganalisis kinerja (performance) penanganan keluhan konsumen terhadap produk IndiHome yang diberikan ke PT. Telkom Tbk; menghitung tingkat kepuasan konsumen terhadap kemampuan PT. Telkom Tbk menangani keluhan konsumen produk IndiHome; merancang Model Penanganan Keluhan Pelanggan Produk Indihome di Kota Ambon; dan merekomendasikan tindakan tindak-lanjut dalam upaya peningkatan penanganan keluhan PT. Telkom Tbk.Metode analisis data yang digunakan adalah analisis deskriptif, Importance-Performance Analysis (IPA), dan Indeks kepuasan konsumen (CSI). Hasil penelitian menunjukantingkat kepentingan atau harapan pelanggan atas penanganan keluhan di PT. Telkom Tbk Wilayah Maluku di Kota Ambon secara keseluruhan berada pada level menengah; persepsi pelanggan atas kinerja penanganan keluhan di perusahaan ini secara keseluruhan berada dalam kategori cukup baik; pelanggan cukup puas dengan kinerja penanganan keluhan oleh perusahaan; Model Penanganan Keluhan Pelanggan Produk Indihome di Kota Ambon menunjukkan peningkatan kualitas hasil penanganan keluhan pelanggan memerlukan peningkatan kinerja pada atribut-atribut kuadran I dan II dengan pembatasan kinerja pada atribut-atribut kuadran III dan IV; dan hal yang perlu dilakukan untuk meningkatkan kepuasan pelanggan atas penanganan keluhan di perusahaan ini adalah penambahan staf customer service, penambahan staf assurance, memberikan pelatihan kepada staf secara berulang terkait dengan masalah-masalah yang dihadapi konsumen, serta memberikan prosedur yang cepat dan mudah.
\end{abstract}

Kata Kunci: Kinerja, Kepuasan, Penanganan Keluhan Pelanggan

\section{PENDAHULUAN}

PT. Telkom Tbk merupakan salah satu perusahaan BUMN yang menyediakan berbagai fasilitas komunikasi untuk memenuhi kebutuhan masyarakat dalam sektor telekomunikasi. Perusahaan ini menyediakan layanan yang beragam (multi service) yaitu layanan suara (telepon), data (internet) dan gambar (IP-TV) dalam satu jaringan akses atau dikenal dengan layanan triple-play. IndiHome merupakan layanan triple-play dari Telkom yang terdiri dari Internet on Fiber atau High Speed Internet, Phone (Telepon Rumah), dan IPTV (UseTV Cable), dimana jumlah konsumen di Kota Ambon sampai bulan November 2016 sudah mencapai 9.475 konsumen, baik perorangan maupun perusahaan.

Mengacu pada penelitian awal, maka dalam sehari, rata-rata konsumen yang melakukan pengaduan sebanyak 53 keluhan untuk semua jenis keluhan seperti modem setting, gangguan masal (gamas), ganti remote use tv, ganti kabel, restart modem dan lain-lain. Sifat kemunculan keluhan bersifat random dengan tingkat kecepatan respon perusahaan yang bervariasi. Perusahaan lebih mendahulukan penanganan keluhan perusahaan/bisnis dari pada konsumen perorangan, namun jumlah konsumen perorangan lebih banyak dari konsumen perusahaan/bisnis. Kebijakan PT. Telkom untuk menyelesaikan permasalahan sesuai keluhan adalah 6 jam setelah keluhan disampaikan khusus kategori konsumen perusahaan non retail, 12 jam bagi konsumen perusahaan tipe retail (toko), sedangkan konsumen perorangan diberi tenggang waktu penyelesaian selama 2x24 jam. Beberapa konsumen perusahaan yang menggunakan paket layanan yang sama paket per orangan, maka prioritas respon keluhannya akan disetarakan dengan kategori konsumen perorangan. Sebaliknya, konsumen perorangan dengan paket layanan setara perusahaan, maka keluhannya akan direspon dengan kebijakan sesuai konsumen perusahaan. Kontradiksi ini menunjukkan ketidakkonsistenan manajemen bisnis yang mengarah pada manajemen keluhan konsumen yang tidak memuaskan. Dengan demikian, sangatlah penting untuk meninjau kembali kebijakan dan praktek manajemen penanganan keluhan konsumen di PT. Telkom Tbk, khususnya untuk produk IndiHome di Kota Ambon. 
Berangkat dari fenomena diatas, penelitian ini dilaksanakanuntuk menganalisis tingkat kepentingan/harapan konsumen produk IndiHome terhadap penanganan keluhan yang diberikan PT. Telkom Tbk; menganalisis kinerja (performance) penanganan keluhan konsumen terhadap produk IndiHome yang diberikan ke PT. Telkom Tbk; menghitung tingkat kepuasan konsumen terhadap kemampuan PT. Telkom Tbk menangani keluhan konsumen produk IndiHome; merancang Model Penanganan Keluhan Pelanggan Produk Indihome di Kota Ambon; dan merekomendasikan tindakan tindak-lanjut dalam upaya peningkatan penanganan keluhan PT. Telkom Tbk.

\section{KAJIAN TEORI DAN METODE}

\section{Penanganan Keluhan}

Penanganan keluhan menurut Tjiptono dan Chandra (2011) mencakup aspek a). Empati terhadap konsumen yang marah; b). Kecepatan dalam penanganan keluhan; c). Kewajaran atau keadilan dalam memecahkan permasalahan atau keluhan; dan d). Kemudahan bagi konsumen untuk menghubungi perusahaan. Lovelock dan Wirtz(2011) menjabarkan aspek-aspek itu sebagai berikut:

1. Empati memiliki 3 dimensi, yaitu acces, communication, dan understanding the customer;

2. Jika keluhan dibuat pada saat penyampaian layanan, maka waktu adalah esensi untuk mencapai pemulihan penuh;

3. Dimensi keadilan mencakup procedural justice; interactional justice; dan outcome justice;

4. Perusahaan perlu memiliki service delivery channel seperti service outlets, frontline employes, dan self-service delivery points.

\section{Kepuasan}

Kepuasan adalah tingkat perasaan seseorang setelah membandingkan kinerja (hasil) yang dirasakan dengan harapannya (Supranto, 2006).Kepuasan timbul karena pemenuhan ekspektasi konsumen setelah memahami pasar, dimana kualitas jasa berperan sangat penting di dalamnya (Aydinlei dan Senyurek, 2016). Dimensi kepuasan pelanggan adalah kualitas produk, harga, mutu pelayanan, emosional, dan kemudahan (Sitinjak, 2008, dalam Prasastono dan Pradaba, 2012).

\section{Analisis Deskriptif}

Analisis deskriptif adalah statistik yang digunakan untuk menganalisis data dengan cara mendeskripsikan atau menggambarkan data yang telah terkumpul sebagaimana adanya tanpa bermaksud membuat kesimpulan yang berlaku untuk umum atau generalisasi (Sugiyono, 2004).Analisis deskriptif terbagi atas dua yaitu berdasarkan ukuran pemusatan data (rataan, median, dan modus) dan ukuran penyebaran data (rentang, varian, dan simpangan baku).

\section{Customer Satisfaction Index (CSI)}

CSI menyatakan tingkat kepuasan konsumen secara menyeluruh dengan melihat tingkat kepentingan dari atribut-atribut produk/jasa, dengan mengikuti tahapan (Aritonang, 2005):

1. TentukanMean Importance Score (MIS)

$n \quad:$ jumlah konsumen

$$
M I S=\frac{\sum_{i=1}^{n} Y_{i}}{n}
$$

$Y_{\mathrm{i}}$ : nilai kepentingan atribut $\mathrm{Y}$ ke-i

2. HitungWeight Factors (WF)

$$
W F=\frac{M I S_{i}}{\sum_{i=1}^{p} M I S_{i}}
$$

3. Hitung Weight Score (WS)

$$
W S_{i}=W F_{i} \times M S S
$$

dimana MSS: Mean Satisfaction Score.

4. Tentukan Customer Satisfaction Index (CSI)

$$
C S I=\frac{\sum_{i=1}^{p} W S_{i}}{H S} \times 100 \%
$$

$p:$ : atribut kepentingan ke-p

HS : (Highest Scale) skala maksimum yang digunakan.

\section{Importance-Performance Analysis (IPA)}

Menurut Supranto (2006) dalam menganalisis data penelitian digunakan metode deskriptif kualitatif-kuantitatif, sedangkan menjawab sejauh mana tingkat kepuasan pelanggan terhadap kinerja, dapat digunakan ImportancePerformance Analysis.Tahapan analisisnya sebagai berikut:

1. Tingkat kesesuaian responden

$$
T K_{i}=\frac{x_{i}}{y_{i}} \times 100 \%
$$

$x_{\mathrm{i}} \quad$ : skor penilaian kinerja perusahaan

$y_{\mathrm{i}}$ : skor penilaian harapan pelanggan 
2. Sumbu $x$ diisi skor tingkat pelaksanaan dan sumbu y diisi skor tingkat harapan. Untuk semua faktor yang mempengaruhi kepuasan dihitung bobot rata-ratanya.

$$
\bar{x}_{i}=\frac{\sum_{i=1}^{k} x_{i}}{n} ; \bar{y}_{i}=\frac{\sum_{i=1}^{k} y_{i}}{n}
$$

3. Membuat diagram kartesius yang dibatasi oleh 2 garis berpotongan, $\overline{\bar{x}}$ dan $\overline{\bar{y}}$.

$$
\overline{\bar{x}}_{i}=\frac{\sum_{i=1}^{k} \bar{x}_{i}}{n} ; \overline{\bar{y}}_{i}=\frac{\sum_{i=1}^{k} \bar{y}_{i}}{n}
$$

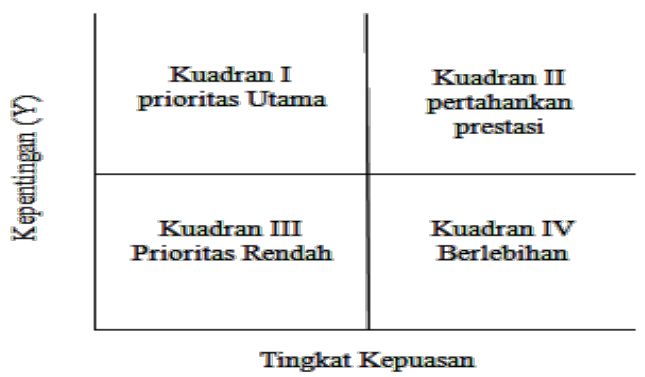

Gambar 1. Kuadran Importance-Performance Analisys (Supranto, 2006)

\section{HASIL DAN PEMBAHASAN}

\section{Analisis Deskriptif}

Rata-rata penilaian tingkat kinerja penanganan keluhan di PT. Telkom Tbk Witel Maluku yaitu 3,20. Penilaian responden terhadap empati terhadap pelanggan yang marah merupakan penilaian tertinggi dibandingkan penilaian terhadap variabel lainnya yaitu 3,27. Penilaian tertinggi kedua yaitu pada variabel kemudahan bagi pelanggan untuk menghubungi perusahaan yaitu 3,20 , penilaian tertinggi ketiga yaitu kewajaran/keadilan dalam memecahkan masalah dan penilaian terendah pada variabel kecepatan dalam penanganan keluahan. Secara keseluruhan responden merasa atribut-atribut penanganan keluhan yang diberikan oleh PT. Telkom Tbk Witel Maluku sudah cukup baik.

$$
\text { Rata-rata penilaian tingkat }
$$

kepentingan/harapan pelanggan terhadap penanganan keluhan yaitu 3,76. Penilaian responden terhadap kemudahan bagi pelanggan untuk menghubungi perusahaan merupakan penilaian tertinggi dibandingkan variabel lainnya yaitu 3,88. Penilaian tertinggi kedua yaitu variabel kewajaran/keadilan dalam memecahkan masalah yaitu sebesar 3.78. Penilaian tertinggi ketiga yaitu empati terhadap pelanggan yang marah yaitu 3,73 dan penailaian terendah pada variabel kecepatan dalam penanganan keluhan yaitu 3,72. Artinya bahwa atribut-atribut penanganan keluhan secara keseluruhan dianggap penting oleh responden.

\begin{tabular}{|c|c|c|c|c|c|}
\hline \multirow{2}{*}{ Variabel } & \multirow{2}{*}{ Atribut } & \multicolumn{2}{|c|}{ Kinerja (X) } & \multicolumn{2}{|c|}{ Kepentingan (Y) } \\
\hline & & Jumlah & Rata-rata & Jumlah & Rata-rata \\
\hline \multirow{8}{*}{ I } & KP1 & 1170 & 2,93 & 1438 & 3,6 \\
\hline & KP2 & 1188 & 2,97 & 1455 & 3,64 \\
\hline & KP3 & 1357 & 3,39 & 1514 & 3,79 \\
\hline & KP4 & 1345 & 3,36 & 1548 & 3,87 \\
\hline & KP5 & 1367 & 3,42 & 1519 & 3,8 \\
\hline & KP6 & 1356 & 3,39 & 1442 & 3,61 \\
\hline & KP7 & 1343 & 3,36 & 1517 & 3,79 \\
\hline & KP8 & 1348 & 3,37 & 1481 & 3,7 \\
\hline \multirow{2}{*}{ II } & KP9 & 1166 & 2,92 & 1472 & 3,68 \\
\hline & KP10 & 1208 & 3,02 & 1498 & 3,75 \\
\hline \multirow{9}{*}{ III } & KP11 & 1294 & 3,24 & 1497 & 3,74 \\
\hline & KP12 & 1282 & 3,21 & 1469 & 3,67 \\
\hline & KP13 & 1356 & 3,39 & 1548 & 3,87 \\
\hline & KP14 & 1400 & 3,5 & 1613 & 4,03 \\
\hline & KP15 & 1297 & 3,24 & 1568 & 3,92 \\
\hline & KP16 & 1261 & 3,15 & 1494 & 3,74 \\
\hline & KP17 & 1274 & 3,19 & 1554 & 3,89 \\
\hline & KP18 & 1155 & 2,89 & 1431 & 3,58 \\
\hline & KP19 & 1172 & 2,93 & 1434 & 3,59 \\
\hline \multirow{2}{*}{ IV } & KP20 & 1325 & 3,31 & 1554 & 3,89 \\
\hline & KP21 & 1231 & 3,08 & 1543 & 3,86 \\
\hline \multicolumn{2}{|c|}{ Total } & 26895 & 67,24 & 31589 & 78,97 \\
\hline
\end{tabular}

Tabel 1. Analisis Deskriptif Tingkat Kinerja dan Tingkat Kepentingan

\section{Analisis Deskriptif}

Indeks kepuasan pelanggan (customer satisfaction index) merupakan indeks untuk menentukan tingkat kepuasan pelanggan secara menyeluruh dengan pendekatan yang mempertimbangkan tingkat kepentingan dari atribut-atribut produk atau jasa yang diukur. Indeks kepuasan pelanggan merupakan analisis kuantitatif berupa persentase pelanggan yang puas dalam suatu survei kepuasan pelanggan. Berikut merupakan contoh perhitungan Indeks kepuasan pelanggan untuk atribut pernyataan Telkom mengenal pelanggannya dengan baik (KP1).

Berdasarkan hasil pengolahan data, nilai Customer Satisfaction Index (CSI) atau Indeks Kepuasan Pelanggan yang diperoleh adalah $64,12 \%$. Hal ini menggambarkan pengguna IndiHome yang menyampaikan keluhan cukup puas atas kinerja penanganan keluhan yang dilakukan oleh PT. Telkom Tbk, tetapi dirasakan masih belum maksimal secara keseluruhan. Untuk memberikan kepuasan yang lebih lagi di masa yang akan datang, maka PT. Telkom Tbk perlu memperbaiki kinerja penanganan keluhan yang belum memuaskan pengguna. 
Tabel 2. Hasil Perhitungan Indeks Kepuasan Pelanggan

\begin{tabular}{|c|c|c|c|c|}
\hline Atribut & $\begin{array}{c}\text { Mean } \\
\text { Importance } \\
\text { Score (MIS) }\end{array}$ & $\begin{array}{c}\text { Importance } \\
\text { Weighting } \\
\text { Factor }(\%)\end{array}$ & $\begin{array}{c}\text { Mean } \\
\text { Satisfaction } \\
\text { Score (MSS) }\end{array}$ & $\begin{array}{c}\text { Weighted } \\
\text { Score }\end{array}$ \\
\hline KP1 & 3,60 & 4,55 & 2,93 & 0,13 \\
\hline KP2 & 3,64 & 4,61 & 2,97 & 0,14 \\
\hline KP3 & 3,79 & 4,79 & 3,39 & 0,16 \\
\hline KP4 & 3,87 & 4,90 & 3,36 & 0,16 \\
\hline KP5 & 3,80 & 4,81 & 3,42 & 0,16 \\
\hline KP6 & 3,61 & 4,56 & 3,39 & 0,15 \\
\hline KP7 & 3,79 & 4,80 & 3,36 & 0,16 \\
\hline KP8 & 3,70 & 4,69 & 3,37 & 0,16 \\
\hline KP9 & 3,68 & 4,66 & 2,92 & 0,14 \\
\hline KP10 & 3,75 & 4,74 & 3,02 & 0,14 \\
\hline KP11 & 3,74 & 4,74 & 3,24 & 0,15 \\
\hline KP12 & 3,67 & 4,65 & 3,21 & 0,15 \\
\hline KP13 & 3,87 & 4,90 & 3,39 & 0,17 \\
\hline KP14 & 4,03 & 5,11 & 3,50 & 0,18 \\
\hline KP15 & 3,92 & 4,96 & 3,24 & 0,16 \\
\hline KP16 & 3,74 & 4,73 & 3,15 & 0,15 \\
\hline KP17 & 3,89 & 4,92 & 3,19 & 0,16 \\
\hline KP18 & 3,58 & 4,53 & 2,89 & 0,13 \\
\hline KP19 & 3,59 & 4,54 & 2,93 & 0,13 \\
\hline KP20 & 3,89 & 4,92 & 3,31 & 0,16 \\
\hline KP21 & 3,86 & 4,88 & 3,08 & 0,15 \\
\hline Tota1 & 78,97 & 100,00 & 67,24 & 3,206 \\
\hline & & & & \\
\hline
\end{tabular}

$$
\begin{gathered}
\mathrm{CSI}=\frac{\sum_{\mathrm{i}=1}^{\mathrm{p}} \mathrm{WSi}}{\mathrm{HS}} \times 100 \%=\frac{3,21}{5} \times 100 \% \\
=64,12 \%
\end{gathered}
$$

\section{Importance-Performance Analysis (IPA) untuk Pemodelan Penanganan Keluhan Pelanggan Produk Indihome di Kota Ambon}

Analisis ini mengaitkan antara tingkat kepentingan (importance) suatu atribut yang dimiliki obyek tertentu dengan kenyataan (performance) yang dirasakan oleh pengguna. Untuk dapat menganalisis IPA perlu diketahui rata-rata tingkat kepentingan dan tingkat kepuasan untuk setiap item dari atribut. Hasil perhitungan rata-rata tingkat kepentingan dan tingkat kinerja dari setiap item dapat dilihat pada Tabel 1 . Berdasarkan Tabel 3, diperoleh nilai rata-rata kesesuaian sebesar $85,14 \%$ yang artinya bahwa secara keseluruhan atribut-atribut tersebut masuk dalam kategori "sesuai". Untuk menentukan titik potong antara sumbu (X) dan sumbu (Y) pada diagram kartesius perlu dilakukannya perbandingan antara total rata-rata pada tingkat kinerja (X) dengan jumlah item pada atribut, serta perbandingan antara total rata-rata tingkat kepentingan (Y) dengan jumlah item pada atribut.

Tabel 3. Hasil Perhitungan Tingkat Kesesuaian

\begin{tabular}{|c|c|c|c|}
\hline \multirow{2}{*}{ Atribut } & \multicolumn{2}{|c|}{ Jumlah } & \multirow{2}{*}{$\begin{array}{c}\text { Tingkat Kesesuaian } \\
\text { Tki }=(\mathrm{Xi} / \mathrm{Yi}) * 100 \%\end{array}$} \\
\cline { 2 - 3 } & Kinerja (X) & Kepentingan (Y) & T1,36\% \\
\hline KP1 & 1170 & 1438 & $81,65 \%$ \\
\hline KP3 & 1188 & 1455 & $89,63 \%$ \\
\hline KP4 & 1357 & 1514 & $86,89 \%$ \\
\hline KP5 & 1367 & 1548 & $89,99 \%$ \\
\hline KP6 & 1356 & 1519 & $94,04 \%$ \\
\hline KP7 & 1343 & 1442 & $88,53 \%$ \\
\hline KP8 & 1348 & 1517 & $91,02 \%$ \\
\hline KP9 & 1166 & 1481 & $79,21 \%$ \\
\hline KP10 & 1208 & 1472 & $80,64 \%$ \\
\hline KP11 & 1294 & 1498 & $86,44 \%$ \\
\hline KP12 & 1282 & 1497 & $87,27 \%$ \\
\hline KP13 & 1356 & 1469 & $87,60 \%$ \\
\hline KP14 & 1400 & 1548 & $86,79 \%$ \\
\hline KP15 & 1297 & 1613 & $82,72 \%$ \\
\hline KP16 & 1261 & 1568 & $84,40 \%$ \\
\hline KP17 & 1274 & 1494 & $81,98 \%$ \\
\hline KP18 & 1155 & 1554 & $80,71 \%$ \\
\hline KP19 & 1172 & 1431 & $81,73 \%$ \\
\hline KP20 & 1325 & 1434 & $85,26 \%$ \\
\hline KP21 & 1231 & 1554 & $79,78 \%$ \\
\hline Rata-rata Tingkat Kesesuaian & 1543 & $85,14 \%$ \\
\hline
\end{tabular}

$$
\overline{\mathrm{X}}=\frac{67,24}{21}=3,20 ; \overline{\mathrm{Y}}=\frac{78,97}{21}=3,76
$$

Hasil Importance-PerformanceAnalysis (IPA) yang digambarkan dalam diagram kartesius menyatakan model kepuasan penanganan keluhan pelanggan produk indihome di Kota Ambon. Diagram itu disajikan sebagai berikut:

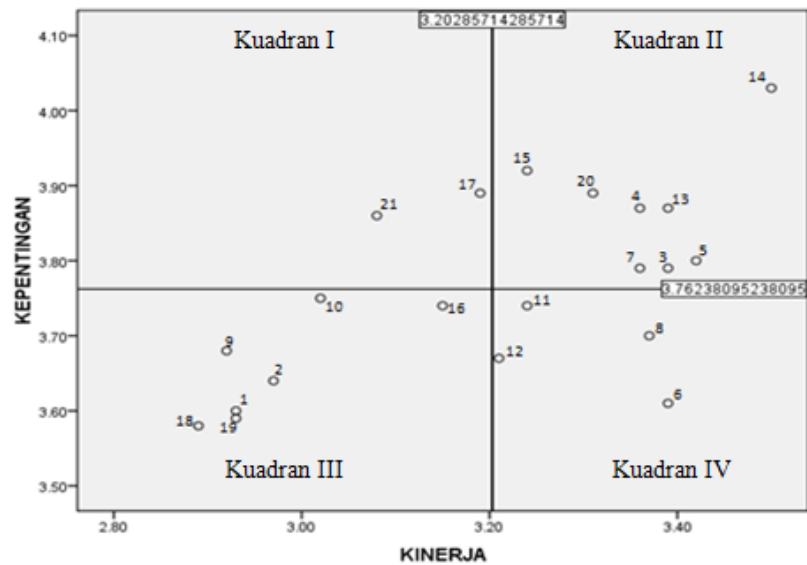

Gambar 2. Model Penanganan Keluhan Pelanggan Produk Indihome di Kota Ambon

Karakteristik dari setiap Kuadran keluhan pelanggan pada model penanganan keluhan pelanggan (Gambar 1) menujukkan tingkat prioritas penanganan keluhan yang beragam. Untuk masing-masing kuadran dapat dijelaskan sebagai berikut:

a. Kuadran I (Prioritas Utama). Atributatribut yang terdapat dalam kuadran ini memiliki tingkat kepentingan yang tinggi menurut responden namun kinerjanya masih 
rendah. Artinya atribut-atribut yang terdapat dalam kuadran ini harus diprioritaskan untuk diperbaiki. Pada kuadran ini terungkap bahwa Staf Assurance Telkom belum mampu memberikan solusi yang memuaskan atas masalah pelanggan (KP17) dan pelanggan kesulitan untuk mendapatkan layanan customer service secara face-to-face (KP21).

b. Kuadran II (Pertahankan Prestasi). Atribut-atribut yang terdapat dalam kuadran ini memiliki tingkat kepentingan yang tinggi dan kinerjanya juga dinilai baik oleh responden. Perusahaan perlu menjaga kualitas dan mempertahankan kinerja dari atributatribut tersebut. Terdapat delapan item atribut yang berada pada kuadran ini yaitu sebagai berikut:

1. Telkom selalu memberikan informasi terbaru kepada pelanggan (KP3)

2. Pelanggan mudah menghubungi Telkom (KP4)

3. Pelanggan mudah berbicara dengan Customer Service (KP5)

4. Telkom Customer Service Telkom mendengarkan keluhan pelanggan dengan baik (KP7)

5. Staf Assurance Telkom bersikap jujur (KP13)

6. Staf Assurance Telkom bersifat sopan (KP14)

7. Staf Assurance Telkom menyelesaikan keluhan pelanggan secara keseluruhan (KP15)

8. Pelanggan dengan mudah mendapatkan informasi melalui media seperti banner, poster, video, dan audio(KP20)

Pada kuadran II berdasarkan dimensinya, item pernyataan KP3,KP4,KP5 dan KP7 termasuk ke dalam dimensi empati terhadap pelanggan yang marah, item pernyataan nomor KP13, KP14, KP15 termasuk kedalam dimensi keadilan dalam memecahkan masalah. Item pernyataan nomor KP20 termasuk dalam dimensi kemudahan bagi pelanggan untuk menghubungi perusahaan.

c. Kuadran III (Prioritas Rendah). Atributatribut yang terdapat dalam kuadran ini memiliki tingkat kepentingan yang rendah dan kinerjanya juga dinilai kurang baik oleh pelanggan. Perusahaan dapat mempertimbangkan untuk peningkatan kinerja terhadap atribut-atribut tersebut walaupun dianggap kurang penting pengaruhnya bagi pelanggan. Terdapat tujuh item atribut yang termasuk dalam kuadran ini yaitu sebagai berikut:

1. Telkom mengenal pelanggannya dengan baik (KP1)

2. Telkom mengetahui apa yang diinginkan pelanggannya (KP2)

3. Staf Assurance Telkom cepat dalam menangani/menyelesaikan keluhan pelanggan (KP9)

4. Staf Assurance Telkom merespon keluhan dalam waktu kurang dari 24 jam (KP10)

5. Staf Assurance Telkom memberikan pemahaman atas kegagalan jasa yang pelanggan alami(KP16)

6. Pelanggan menerima kompensasi dari Telkom (KP18)

7. Pelanggan merasa senang dengan kompensasi yang diberikan oleh Telkom (KP19)

Pada kuadran III berdasarkan dimensinya, item pernyataan KP1 dan KP2 termasuk dalam dimensi empati terhadap pelanggan yang marah, item pernyataan KP9 dan KP10 termasuk ke dalam dimensi kecepatan dalam penanganan keluhan, item pernyataan KP16, KP18 dan KP19 termasuk dalam dimensi keadilan dalam memecahkan masalah.

d. Kuadran IV (Berlebihan). Atribut-atribut yang terdapat dalam kuadran ini memiliki tingkat kepentingan yang rendah menurut responden namun memiliki kinerja yang baik sehingga dianggap berlebihan oleh responden. Peningkatan kinerja pada atribut-atribut ini hanya akan menyebabkan terjadinya pemborosan sumber daya. Terdapat 4 item atribut yang termasuk dalam kuadran ini yaitu sebagai berikut:

1. Customer Service Meminta Maaf atas kegagalan jasa yang saya alami (KP6)

2. Customer Service Telkom mengucapkan terima kasih atas penyampaian keluhan yang pelanggan lakukan (KP8)

3. Prosedur yang dilakukan Telkom bersifat responsif (KP11)

4. Telkom mendengarkan saran dari pelanggan (KP12)

Pada kuadran IV berdasarkan dimensinya, item pernyataan KP6 dan KP8 termasuk dalam dimensi empati terhadap pelanggan yang marah, item pernyataan KP11 dan KP12 termasuk ke dalam dimensi keadilan dalam memecahkan masalah. 


\section{Kepuasan Pelanggan Indihome dari Perspektif Penanganan Keluhan Pelanggan}

Tingkat kepuasan pelanggan terhadap layanan penanganan keluhan PT. Telkom Tbk Wilayah Maluku dalam menanggapi keluhan mereka terukur berdasarkan nilai Customer Satisfaction Index (CSI). Prestasi perusahaan ini hanya mampu memuaskan $64,12 \%$ keluhan yang disampaikan pelanggan indihome. Sistem layanan keluhan belum optimal menyajikan solusi yang mengatasi permasalahan pelanggan. Dalam hal ini, harapan (kepentingan) pelanggan tergadap tindakan penanganan keluhan yang akan diterimanya ternyata cukup berbeda dengan realisasi tindakan (kinerja) perusahaan terhadap keluhan tersebut.

Mengacu pada Model Penanganan Keluhan Pelanggan Produk Indihome di Kota Ambon (Gambar 1), kontributor utama pada tingkat kepuasan sedang (cukup memuaskan) adalah nilai atribut kuadran I, II, III dan IV. Dari perspektif pelanggan, PT. Telkom Tbk Wilayah Maluku terdapat beberapa fenomena penting:

a. Sebaran tingkat kepentingan berada pada level yang cenderung sama, yaitu pada level menegah. Untuk fenomena ini, perubahan nilai CSI (tingkat kepuasan) ditentukan hanya oleh nilai tingkat kinerja atau sejauhmana pencapaian yang ditunjukkan oleh PT. Telkom Tbk Wilayah Maluku pada atributatribut tersebut. Pencapaian level menengah pada tingkat kinerja menunjukkan upaya perusahaan ini belum maksimal;

b. Perusahaan ini cenderung melakukan pemborosan dengan mengupayakan pemenuhan atribut penanganan keluhan pada kuadran III dan IV, yang mana memiliki tingkat kepentingan dibawah rata-rata. Suatu perlambatan yang diciptakan perusahaan sendiri disebabkan karena besarnya usaha (kinerja) yang dilakukan untuk memenuhi atribut pada kuadran I dan II adalah censerung tidak berbeda jauh dengan usaha yang dilakukan pada kuadran III dan IV (nilai tingkat kinerja berada antara 2,89 sampai 3,42). Ini menunjukkan adanya ketidakpahaman perusahaan akan apa yang menjadi kebutuhan pelanggan secara spesifik. Pemetaan akan keberhasilan layanan indihome perlu lagi dilakukan berdasarkan faktor-faktor yang berpengaruh seperti atribut kualitas jasa yang digunakan dalam penelitian ini. Penurunan kinerja atribut kuadran III dan
IV dan pemanfaatan semua potensi perusahaan yang ada guna meningkatkan kinerja atribut pada kuadran I dan II akan mendorong peningkatan kepuasan pelanggan.

Hal-hal kritis yang perlu dilakukan untuk mendorong peningkatan tingkat kepuasan pelanggan terhadap penanganan keluhan oleh PT. Telkom Tbk. Wilayah Maluku meliputi:

a. Penetapan target optimal bagi nilai kinerja atribut pada kuadran III dan IV;

b. Penetapan target minimum bagi nilai kinerja atribut pada kuadran I dan II;

c. Menguraikan keterkaitan antar atribut untuk merumuskan strategi implementasi penanganan keluhan pelanggan.

\section{Tindak lanjut Model Penanganan Keluhan}

Berdasarkan hasil Importance-Performance Analysis (IPA) pada model Penanganan Keluhan Pelanggan Produk Indihome di Kota Ambon (gambar 1), atribut-atribut penanganan keluhan yang perlu diperbaiki yaitu atribut-atribut yang barada pada kuadran I dan kuadran III.

Atribut-atribut penanganan keluhan pada kuadran I dianggap mempengaruhi kepuasan pelanggan namun perusahaan belum melaksanakannya sesuai dengan harapan pelanggan. Hal yang dapat dilakukan untuk memperbaiki atribut-atribut pada kuadaran I diantaranya, perusahaan perlu memberikan pelatihan kepada staf Assurance secara berkelanjutan terkait dengan penyelesaian masalah-masalah yang sering dihadapi oleh pelanggan. Perusahaan juga perlu menambah staf pada Customer Service untuk melayani pelanggan yang menyampaikan keluhan secara face-to-face.

Perusahaan juga perlu mempertimbangkan perbaikan kinerja pada atribut-atribut pada kuadran III walaupun dianggap kurang penting pengaruhnya bagi pelanggan. Atribut-atribut yang diprioritaskan untuk perbaikan kinerja layanan penanganan yaitu staf assurance Telkom cepat dalam menangani/menyelesaikan keluhan (KP9) dan pelanggan menerima kompensasi dari telkom (KP18). Hal yang dapat dilakukan untuk perbaikan atribut-atribut tersebut yaitu perusahaan dapat menambah staf assurance untuk mempercepat penyelesaian masalah yang dialami pelanggan serta perusahaan perlu memberikan kompensasi kepada pelanggan atas kegagalan jasa yang dialami. Disamping itu perlu dilakukan sosialisasi secara efektif tentang sistem kompensasi terhadap kegagalan sistem layanan 
indihome. Hal ini akan sangat bermanfaat untuk menciptakan konsumen loyal dan meningkatkan loyalitas mereka.

Atribut-atribut pada kuadran IV juga perlu untuk diperbaiki dalam artian bahwa kinerja pada atribut-atribut tersebut perlu untuk ditinjau kembali untuk mencegah adanya pemborosan. Hal yang dapat dilakukan seperti perusahaan tidak harus melaksanakan semua saran yang diberikan oleh pelanggan, perlu ada seleksi terhadap saransaran tersebut untuk dapat menjawab sebagian besar masalah yang dihadapi.

\section{KESIMPULAN}

1. Tingkat Kepentingan atau harapan pelanggan atas penanganan keluhan di PT. Telkom Tbk Witel Maluku secara keseluruhan berada pada level menengah yaitu diantara cukup penting (3.00) dan penting (4.00);

2. Persepsi pelanggan atas kinerja penanganan keluhan di PT. Telkom Tbk Witel Maluku secara keseluruhan berada dalam kategori cukup baik (nilai rata-rata sebesar 3,20);

3. Tingkat kepuasan pengguna IndiHome pada PT. Telkom Tbk Witel Maluku adalah sebesar $64,12 \%$, yangmenyatakan bahwa pelanggan merasa cukup puas dengan kinerja penanganan yang diberikan oleh PT. Telkom Tbk Witel Maluku;

4. Model Penanganan Keluhan Pelanggan Produk Indihome di Kota Ambon menunjukkan peningkatan kualitas hasil penanganan keluhan pelanggan memerlukan peningkatan kinerja pada atribut-atribut kuadran I dan II dengan pembatasan kinerja pada atribut-atribut kuadran III dan IV;

5. Hal yang perlu dilakukan untuk meningkatkan kepuasan pelanggan atas penanganan keluhan di PT. Telkom Tbk Witel Maluku adalah penambahan staf customer service, penambahan staf assurance, memberikan pelatihan kepada staf secara berulang terkait dengan masalah-masalah yang dihadapi konsumen, serta memberikan prosedur yang cepat dan mudah.

\section{DAFTAR PUSTAKA}

Aritonang, R. L. 2005. Kepuasan Pelanggan. Gramedia, Jakarta.

Aydinli, C. dan Senyurek, E. 2016. Measuring Impact of Service Quality Dimensions on Customers Satisfaction: case of GSM Users in Poland. International Journal of Academic Research in Accounting, Finance and Management Sciences, Vol. 6, No. 1. P127133.

Lovelock, C. dan Wirtz. J. 2011. Service Marketing. New Jersey, Pearson. USA.

Prasastono, N. dan Pradaba, S. Y. F. 2012. Kualitas Produk dan Kualitas Pelayanan terhadap Kepuasan Konsumen Kentucky Fried Chiken Semarang Candi. Jurnal Dinamika Kepariwisataan, Vol. XI, No. 2.Tersedia pada https://www.google.co.id/url?sa=t\&rct=j\&q= \&esrc $=$ s\&source $=$ web\&cd $=21 \& c a d=r j a \& u a c$ $\mathrm{t}=8 \& \mathrm{ved}=0$ ahUKEwi1 1e73ioLYAhWIpo8K HVnwAEg4FBAWCCUwAA\&url=https $\% 3$ A\%2F\%2Fwww.unisbank.ac.id\%2Fojs\%2Fi ndex.php\%2Fpdk1\%2Farticle\%2Fdownload $\% 2 \mathrm{~F} 1716 \% 2 \mathrm{~F} 630 \&$ usg=AOvVaw028Z1SGldWgkvQ75E12YJ [16 November 2017].

Sugiyono. 2004. Metode Penelitian Bisnis. Alfabeta. Bandung.

Supranto, J. 2006. Pengukuran Tingkat Kepuasan Pelanggan: Untuk Menaikkan Pangsa Pasar. Rineka Cipta. Jakarta. Tersedia pada ejournal.undip.ac.id/index.php/jgti/article/do wnload/2112/1857 [16 November 2017].

Tjiptono, F. dan Chandra, G. 2011. Service, Quality and Satisfaction. Edisi Ketiga, Penerbit Andi. Yogyakarta. 